\title{
The developed Arabic version of the Hearing Handicap Inventory for the Elderly
}

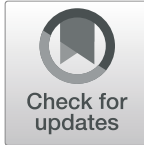

N. Ismail', A. Shalaby², R Behairy ${ }^{1 *}, H$. Khodary $^{3}$ and M. Ashraf ${ }^{3}$

\begin{abstract}
Background: Hearing impairment ranks third on the list of chronic health conditions of the elderly, after arthritis and hypertension. As average lifespans increase, it is likely that the proportion of people with hearing loss will also increase. The purpose of the study was to develop, standardize, and apply an Arabic version of the Hearing Handicap Inventory for the Elderly (HHIE).

Results: The mean age of the 100 subjects included in the pretest was $64.92 \pm 5.937$ with age ranged from 60 to 84 years. The average score for each item (simple, clear, and relevant) for each separate question obtained more than $80 \%$ which is considered valid. One hundred percent of the participants reported that the entire inventory appeared simple, clear, and relevant, we further implied the jury opinion; the total score average of our jury for the entire inventory was calculated to determine the face validity of the questionnaire and found to be $89.81 \%$.

Responses of all participants for each question were collected and showed questions 8, 21, 6, 7, and 14 obtained the highest response results for both yes and sometimes. The HHIE showed high reliability $(p$ value $<0.001)$ for all questions. The demographic data of the forty participants showed no statistically significant difference between the complaining group of hearing loss and the non-complaining group as regards age and gender. There was a highly statistically significant difference between the complaining group and the non-complaining group regarding the HHIE. The sensitivity of the HHIE was 79\% for severe auditory handicapping and only $24 \%$ for mild-to-moderate auditory handicapping.

Conclusion: The developed Arabic version of the HHIE has high reliability, validity, simplicity, and clarity which found consistent with the original English questionnaire and it performed well in the detection of hearing loss in elderly Egyptians. It can be applied in a large population and for use in surveys.
\end{abstract}

Keywords: Aging, Hearing Handicap Inventory for the Elderly

\section{Background}

Hearing is an important sensation for the elderly, in whom it promotes quality of life and helps to maintain safety and wellness. For example, normal hearing enables people to notice alarm sounds, to respond to stimuli even when they are sleeping and/or in the dark, to detect sounds issuing from behind them, to communicate efficiently with other people, and to maintain links to the world via telephones and radios. These benefits can be

\footnotetext{
* Correspondence: drredabehairy@yahoo.com

${ }^{1}$ ENT Department, Faculty of Medicine for Girls, Al-Azhar University, Cairo, Egypt

Full list of author information is available at the end of the article
}

particularly important after people have retired from work. Unfortunately, age-related hearing loss seems to be a growing problem [1].

A hearing handicap is thought to be a complex phenomenon that involves far more than just hearing impairment, meaning that it cannot be fully characterized by audiometry alone. Instead, evaluation is usually carried out via a self-reported questionnaire inquiring into the emotional and social effects of hearing impairment [2]. Numerous self-assessment instruments have been developed during the past 30 years for determination of the presence of hearing handicaps, but only a limited number of these instruments have been designed 
and standardized exclusively for use with elderly populations $[3,4]$. Among them, the Hearing Handicap Inventory for the Elderly (HHIE) is a self-assessment instrument that is recommended by the American Speech-Language-Hearing Association [5, 6].

The aim of this study was to develop and evaluate an Arabic version of the HHIE, to facilitate the early detection of hearing impairment through self-evaluation. This version of the HHIE can be used in addition to basic audiological evaluation.

\section{Methods}

The study methodology was reviewed and approved by staff of the Community Department, Faculty of Medicine, Ain Shams University. The permission from the original author was obtained then translation and cultural adaptation of hearing handicap inventory for the elderly questionnaire (HHIE) was produced by the following stages according to [7].

\section{Stage 1: Translation of the HHIE}

HHIE was translated into Arabic (forward translation) by two bilingual translators whose mother tongue is Arabic, one of them is a professional translator and has a certified linguistic competency, and the other one is a healthcare professional in the Community Department. Later, an English-certified translation of our Arabic version of the HHIE was done (back translation) by professional translators in a blinded way. All translations were reviewed by the authors and some staff of the Community Department, Faculty of Medicine, Ain Shams University.

\section{Stage 2: Cultural adaptation of the Arabic HHIE and pretesting of the adapted form}

HHIE was modified to make it culturally appropriate, we used "not hearing or discriminating voices well" instead of the general term "hearing problem." This was due to the need of using more comprehensive terms suitable for different participants. In most questions, we used a comparison approach between past and current time instead of only current time approach used in the original inventory. We used "did you become" instead of "does cause you." This was done for the purpose of eliciting the memory for any change in the participant lifestyle. These questions are 1, 2, 3, 4, 5, 7, 9, 11, 12, 13, 14, 16, 17, 18, 19, 22, 23, 24, and 25. The final Arabic HHIE and suggested authors modifications were tested in a face to face interview $95 \%$ or written (pen to paper) $5 \%$ of 100 elderly Egyptians randomly collected from three different pools: Al-Zahraa University Hospital outpatient clinic (audiology and ENT clinics were excluded), railway station, and post office in Nasr City, Cairo. They have the ability to read andlor understand Arabic and are not diagnosed with hearing loss. For the purpose of content and face validity assessment, the modified Arabic HHIE was presented to a jury of experts which consisted of ten members working in the field of audiology, to obtain their opinions on the degree of relevance to the subject, simplicity, and clarity. Both participants' and experts' opinion as regards face validity were collected in this study. Responses of all participants for each question were collected and the alpha Cronbach's coefficient was done to measures its internal consistency and reliability of each item. Reliability means the consistency or repeatability of the measure. A reliable measure is defined by its consistency. The internal consistency of each item or single question as a correlation between all 100 participants' responses of each question was calculated.

\section{Stage 3}

A new group of 40 consecutive subjects were $>60$ years. The twenty of them, had no complaints of hearing loss, were chosen randomly from outpatient clinics of $\mathrm{Al}$ Zahraa University Hospital, Cairo, Egypt. The other twenty individuals had complaints of hearing loss and came to seek medical advice in the Audiology Unit at Al-Zahraa University Hospital. The mean age in the subgroup with no complaints of hearing loss $(n=20)$ was 64.9 years, the mean age in the subgroup with complaints of hearing loss $(n=20)$ was 64.8 years. The subgroup with no complaints of hearing loss consisted of $45 \%$ women and $55 \%$ men, the subgroup with complaints of hearing loss contained 40\% women and $60 \%$ men. They consisted of co-operative individuals with no history of neurological diseases or motion problems. Initially, the subjects were given general instructions of the HHIE by the researcher.

The Arabic version was administered either by pen or in a face to face interview for illiterate subjects. Individuals respond "yes," "sometimes," or "no" to the questions that were scored 4, 2, or 0 , respectively; the total score ranged from 0 to 100 . The test comprises 25 questions that cover different aspects of a hearing handicap. The HHIE is calibrated so that high total scores indicate the presence of a hearing handicap: $0-16=$ no handicap, $17-42=$ mild-to-moderate handicap, and $>43=$ severe handicap. After administration of the HHIE was completed, all subjects underwent otoscopic examination and audiometric testing by an audiologist blinded to the HHIE results.

For each participant, pure-tone audiometry (PTA) was performed using an AC40 audiometer (Interacoustics). The hearing threshold grading was as follows: $0-25 \mathrm{~dB}$, normal hearing; $26-40 \mathrm{~dB}$, mild hearing loss; $41-60 \mathrm{~dB}$, moderate hearing loss; $61-80 \mathrm{~dB}$, severe hearing loss; and $>81 \mathrm{~dB}$, profound hearing loss [8-10]. Immittancemetry 
was performed using an Interacoustics AT235 automatic middle-ear analyzer.

\section{Statistical analysis}

Data were analyzed with SPSS software (version 23.0, IBM, Armonk, NY, USA). Qualitative data were reported as the numbers and percentages of occurrences in each category. Associations between categorical variables were assessed using the Chi-square test to compare expected and observed distribution frequencies. The alpha Cronbach's coefficient measures the validity (the internal consistency among a group of items combined to form a single scale). A correlation coefficient of $\geq 0.70$ is considered good.

\section{Results}

\section{Result of the pretest stage}

The mean age of the 100 subjects included in the pretest was $64.92 \pm 5.937$ with age ranged from 60 to 84 years. They included 60 males and 40 females (Table 1). The average score for each item (simple, clear, and relevant) for each separate question obtained more than $80 \%$ which is considered valid. The participants were asked for their personal judgment about the Arabic inventory as a whole and general appearance as regards simple, clear (well constructed), and relevant. One hundred percent of the participants reported that the entire inventory appeared simple, clear, and relevant; we further implied the jury opinion; the total score average of our jury for the entire inventory was calculated to determine the face validity of the questionnaire and found to be 89.81\% (Table 2). Responses of all participants for each question were collected and showed questions $8,21,6$, 7 , and 14 obtained the highest response results for both yes and sometimes (Table 3 ). The HHIE showed high reliability ( $p$ value $<0.001$ ) for all questions (Table 4 ).

\section{Results of stage 3}

The demographic data of the forty participants showed no statistically significant difference between the complaining group of hearing loss and the non-complaining group as regards age and gender (Table 5).There was a highly statistically significant difference between the

Table 1 Descriptive data of the study groups (100 subjects) in the pretest stage

\begin{tabular}{llrr}
\hline Age & Range & $60.00-84.00$ \\
& Mean \pm SD & $64.92 \pm$ & 5.93 \\
Gender & Male & 60 & $60 \%$ \\
& Female & 40 & $40 \%$ \\
\multirow{2}{*}{ Locus } & Post office & 35 & $35 \%$ \\
& Railway station & 20 & $20 \%$ \\
& Al-Zahraa University Hospital outpatient clinic & 45 & $45 \%$ \\
\hline
\end{tabular}

Table 2 Jury score: average and percentage

\begin{tabular}{|c|c|c|c|}
\hline & Average & $\%$ & Total (face validity) \\
\hline Q1 & 4.67 & 93.33 & \\
\hline Q2 & 4.53 & 90.67 & \\
\hline Q3 & 4.60 & 92.00 & \\
\hline Q4 & 4.40 & 88.00 & \\
\hline Q5 & 4.40 & 88.00 & \\
\hline Q6 & 4.67 & 93.33 & \\
\hline Q7 & 4.67 & 93.33 & \\
\hline Q8 & 4.47 & 89.33 & \\
\hline Q9 & 4.33 & 86.67 & \\
\hline Q10 & 4.60 & 92.00 & \\
\hline Q11 & 4.40 & 88.00 & \\
\hline Q12 & 4.53 & 90.67 & \\
\hline Q13 & 4.60 & 92.00 & \\
\hline Q14 & 4.20 & 84.00 & \\
\hline Q15 & 4.80 & 96.00 & \\
\hline Q16 & 4.67 & 93.33 & \\
\hline Q17 & 4.33 & 86.67 & \\
\hline Q18 & 4.60 & 92.00 & \\
\hline Q19 & 4.47 & 89.33 & \\
\hline Q20 & 4.67 & 93.33 & \\
\hline Q21 & 4.00 & 80.00 & \\
\hline Q22 & 4.33 & 86.67 & \\
\hline Q23 & 4.60 & 92.00 & \\
\hline Q24 & 4.40 & 88.00 & \\
\hline Q25 & 4.33 & 86.67 & \\
\hline Total & 4.49 & & $89.81 \%$ \\
\hline
\end{tabular}

complaining group and the non-complaining group regarding the HHIE (Table 6). The sensitivity of the HHIE was $79 \%$ for severe auditory handicapping and only $24 \%$ for mild-to-moderate auditory handicapping.

\section{Discussion}

The HHIE is an established self-assessment tool that is designed to measure the effects of hearing impairment on the emotional and social adjustment of elderly people. In the present study, questions S8, S21, S6, E7, and E14, respectively, obtained the highest response. The first three of those questions were situational, and the last two were emotional (Table 3). A study of self-reported health and hearing loss status as well as associated factors of elderly persons aged $\geq 60$ years, questionnaires included HHIE-S was applied. Questions which obtained the highest score were, respectively, question $S$ (problem hearing the television/radio?), question $S$ (difficulty when visiting friends?), question $S$ (trouble hearing whispers?), question S (difficulty when visiting friends?), question $\mathrm{E}$ (embarrassed 
Table $\mathbf{3}$ Total responses for each question

\begin{tabular}{|c|c|c|c|c|c|c|}
\hline \multirow[t]{2}{*}{ Question } & \multicolumn{2}{|l|}{ No } & \multicolumn{2}{|c|}{ Yes } & \multicolumn{2}{|c|}{$\begin{array}{l}\text { Some } \\
\text { time }\end{array}$} \\
\hline & $N$ & $\%$ & N & $\%$ & N & $\%$ \\
\hline 1. Did your use the telephone become less than in past because of not hearing or discriminating the voices well? & 86 & 86.00 & 3 & 3.00 & 11 & 11.00 \\
\hline $\begin{array}{l}\text { 2. Did you become feeling embarrassed when you meet strange persons because of not hearing or discriminating } \\
\text { the voices well? }\end{array}$ & 84 & 84.00 & 1 & 1.00 & 15 & 15.00 \\
\hline $\begin{array}{l}\text { 3. Did you become avoiding dealing with big groups of people because of not hearing or discriminating the voices } \\
\text { well? }\end{array}$ & 94 & 94.00 & 1 & 1.00 & 5 & 5.00 \\
\hline 4. Did you become feeling more irritable than in the past because of not hearing or discriminating the voices well? & 82 & 82.00 & 0 & 0.00 & 18 & 18.00 \\
\hline $\begin{array}{l}\text { 5. Did you become feeling frustrated when you talk to your family members because of not hearing or } \\
\text { discriminating the voices well? }\end{array}$ & 89 & 89.00 & 1 & 1.00 & 10 & 10.00 \\
\hline $\begin{array}{l}\text { 6. Do you face difficulties when you are present in social occasions because of not hearing or discriminating the } \\
\text { voices well? }\end{array}$ & 63 & 63.00 & 3 & 3.00 & 34 & 34.00 \\
\hline $\begin{array}{l}\text { 7. Did you become feeling difficulties in understanding the matters well because of not hearing or discriminating the } \\
\text { voices well? }\end{array}$ & 65 & 65.00 & 2 & 2.00 & 33 & 33.00 \\
\hline $\begin{array}{l}\text { 8. Do you face a difficulty during talking to you in low voice because of not hearing or discriminating the voices } \\
\text { well? }\end{array}$ & 40 & 40.00 & 6 & 6.00 & 54 & 54.00 \\
\hline $\begin{array}{l}\text { 9. Did you become feeling any kind of handicap in your life because of not hearing or discriminating the voices } \\
\text { well? }\end{array}$ & 94 & 94.00 & 0 & 0.00 & 6 & 6.00 \\
\hline $\begin{array}{l}\text { 10. Did you become feeling difficulties during visiting your relative and acquaints because of not hearing or } \\
\text { discriminating the voices well? }\end{array}$ & 94 & 94.00 & 0 & 0.00 & 6 & 6.00 \\
\hline $\begin{array}{l}\text { 11. Did attending your religious rituals become less than in the past because of not hearing or discriminating the } \\
\text { voices well? }\end{array}$ & 98 & 98.00 & 0 & 0.00 & 2 & 2.00 \\
\hline $\begin{array}{l}\text { 12. Did you become more nervous and effervescent than in the past because of not hearing or discriminating the } \\
\text { voices well? }\end{array}$ & 91 & 91.00 & 1 & 1.00 & 8 & 8.00 \\
\hline $\begin{array}{l}\text { 13. Did your visitings to your relatives and acquaints become less than in the past because of not hearing or } \\
\text { discriminating the voices well? }\end{array}$ & 96 & 96.00 & 1 & 1.00 & 3 & 3.00 \\
\hline $\begin{array}{l}\text { 14. Did the engagement in a debate with your family members become more because of not hearing or } \\
\text { discriminating the voices well? }\end{array}$ & 76 & 76.00 & 0 & 0.00 & 24 & 24.00 \\
\hline $\begin{array}{l}\text { 15. Do you face a difficult when you hear the voice of the radio or television because of not hearing or } \\
\text { discriminating the voices well? }\end{array}$ & 84 & 84.00 & 1 & 1.00 & 15 & 15.00 \\
\hline $\begin{array}{l}\text { 16. Did your going to the market become less than in the past because of not hearing or discriminating to the } \\
\text { voices well? }\end{array}$ & 96 & 96.00 & 0 & 0.00 & 4 & 4.00 \\
\hline $\begin{array}{l}\text { 17. Did you become feeling more annoyed and disturbed more than in the past because of not hearing or } \\
\text { discriminating the voices well? }\end{array}$ & 82 & 82.00 & 0 & 0.00 & 18 & 18.00 \\
\hline 18. Did you become wishing to be alone because of not hearing or discriminating the voices well? & 94 & 94.00 & 0 & 0.00 & 6 & 6.00 \\
\hline $\begin{array}{l}\text { 19. Did the talking to your family individuals become less than in the past because of not hearing or discriminating } \\
\text { the voices well? }\end{array}$ & 95 & 95.00 & 1 & 1.00 & 4 & 4.00 \\
\hline $\begin{array}{l}\text { 20. Do you face difficulties and obstacles that affect your personal or social life because of not hearing or } \\
\text { discriminating to the voices well? }\end{array}$ & 96 & 96.00 & 1 & 1.00 & 3 & 3.00 \\
\hline $\begin{array}{l}\text { 21. Do you face difficulties when you are in the restaurants or the crowded eating places because of not hearing or } \\
\text { discriminating the voices well? }\end{array}$ & 60 & 60.00 & 2 & 2.00 & 38 & 38.00 \\
\hline $\begin{array}{l}\text { 22. Do you become feeling more frustrated or depressed more than in the past because of not hearing or } \\
\text { discriminating the voices well? }\end{array}$ & 91 & 91.00 & 1 & 1.00 & 8 & 8.00 \\
\hline $\begin{array}{l}\text { 23. Did your listening to the voice of the radio or the television become less than in the past because of not hearing } \\
\text { or discriminating the voices well? }\end{array}$ & 94 & 94.00 & 2 & 2.00 & 4 & 4.00 \\
\hline $\begin{array}{l}\text { 24. Did you become feeling discomfort during talking to the friends or acquaints because of not hearing or } \\
\text { discriminating the voices well? }\end{array}$ & 85 & 85.00 & 0 & 0.00 & 15 & 15.00 \\
\hline $\begin{array}{l}\text { 25. Did you become feeling disregarded and isolated during your presence with the people because of not hearing } \\
\text { or discriminating the voices well? }\end{array}$ & 96 & 96.00 & 0 & 0.00 & 4 & 4.00 \\
\hline
\end{tabular}

when meeting new people?), and then question $\mathrm{E}$ (hearing limiting your personal life?) [11].These study results were different from those obtained by the present study, except for the "trouble hearing whispers?" question. In the present study, most of the highest score questions are situational. 
Table 4 Consistency for each question: $r$ score and $P$ value

\begin{tabular}{|c|c|c|}
\hline \multirow[t]{2}{*}{ Question } & \multicolumn{2}{|c|}{ Total score } \\
\hline & $r$ & $P$ value \\
\hline 1. Did your use the telephone become less than the in past because of not hearing or discriminating the voices well? & 0.581 & $<0.001$ \\
\hline $\begin{array}{l}\text { 2. Did you become feeling embarrassed when you meet strange persons because of not hearing or discriminating } \\
\text { the voices well? }\end{array}$ & 0.569 & $<0.001$ \\
\hline 3. Did you become avoiding dealing with big groups of people because of not hearing or discriminating the voices well? & 0.496 & $<0.001$ \\
\hline 4. Did you become feeling more irritable than in the past because of not hearing or discriminating the voices well? & 0.543 & $<0.001$ \\
\hline $\begin{array}{l}\text { 5. Did you become feeling frustrated when you talk to your family members because of not hearing or discriminating } \\
\text { the voices well? }\end{array}$ & 0.470 & $<0.001$ \\
\hline 6. Do you face difficulties when you are present in social occasions because of not hearing or discriminating the voices well? & 0.479 & $<0.001$ \\
\hline $\begin{array}{l}\text { 7. Did you become feeling difficulties in understanding the matters well because of not hearing or discriminating the } \\
\text { voices well? }\end{array}$ & 0.570 & $<0.001$ \\
\hline 8. Do you face a difficulty during talking to you in low voice because of not hearing or discriminating the voices well? & 0.443 & $<0.001$ \\
\hline 9. Did you become feeling any kind of handicap in your life because of not hearing or discriminating the voices well? & 0.524 & $<0.001$ \\
\hline $\begin{array}{l}\text { 10. Did you become feeling difficulties during visiting your relative and acquaints because of not hearing or discriminating } \\
\text { the voices well? }\end{array}$ & 0.771 & $<0.001$ \\
\hline 11. Did attending your religious rituals become less than in the past because of not hearing or discriminating the voices well? & 0.431 & $<0.001$ \\
\hline 12. Did you become more nervous and effervescent than in the past because of not hearing or discriminating the voices well? & 0.518 & $<0.001$ \\
\hline $\begin{array}{l}\text { 13. Did your visitings to your relatives and acquaints become less than in the past because of not hearing or discriminating } \\
\text { the voices well? }\end{array}$ & 0.656 & $<0.001$ \\
\hline $\begin{array}{l}\text { 14. Did the engagement in a debate with your family members become more because of not hearing or discriminating } \\
\text { the voices well? }\end{array}$ & 0.536 & $<0.001$ \\
\hline $\begin{array}{l}\text { 15. Do you face a difficult when you hear the voice of the radio or television because of not hearing or discriminating the } \\
\text { voices well? }\end{array}$ & 0.511 & $<0.001$ \\
\hline 16. Did your going to the market become less than in the past because of not hearing or discriminating to the voices well? & 0.597 & $<0.001$ \\
\hline $\begin{array}{l}\text { 17. Did you become feeling more annoyed and disturbed more than in the past because of not hearing or discriminating } \\
\text { the voices well? }\end{array}$ & 0.607 & $<0.001$ \\
\hline 18. Did you become wishing to be alone because of not hearing or discriminating the voices well? & 0.611 & $<0.001$ \\
\hline $\begin{array}{l}\text { 19. Did the talking to your family individuals become less than in the past because of not hearing or discriminating the } \\
\text { voices well? }\end{array}$ & 0.595 & $<0.001$ \\
\hline $\begin{array}{l}\text { 20. Do you face difficulties and obstacles that affect your personal or social life because of not hearing or discriminating to } \\
\text { the voices well? }\end{array}$ & 0.624 & $<0.001$ \\
\hline $\begin{array}{l}\text { 21. Do you face difficulties when you are in the restaurants or the crowded eating places because of not hearing or } \\
\text { discriminating the voices well? }\end{array}$ & 0.504 & $<0.001$ \\
\hline $\begin{array}{l}\text { 22. Do you become feeling more frustrated or depressed more than in the past because of not hearing or discriminating } \\
\text { the voices well? }\end{array}$ & 0.477 & $<0.001$ \\
\hline $\begin{array}{l}\text { 23. Did your listening to the voice of the radio or the television become less than in the past because of not hearing or } \\
\text { discriminating the voices well? }\end{array}$ & 0.540 & $<0.001$ \\
\hline $\begin{array}{l}\text { 24. Did you become feeling discomfort during talking to the friends or acquaints because of not hearing or discriminating } \\
\text { the voices well? }\end{array}$ & 0.606 & $<0.001$ \\
\hline $\begin{array}{l}\text { 25. Did you become feeling disregarded and isolated during your presence with the people because of not hearing or } \\
\text { discriminating the voices well? }\end{array}$ & 0.549 & $<0.001$ \\
\hline
\end{tabular}

In this study, the internal consistency of each item or single question as a correlation between all 100 participants' responses of each question was calculated and showed high reliability (Table 4). The present results were close to those in the original study done by [2]. According to Ventry and Weinstein, the reliability of the HHIE was evaluated by the computation of Cronbach's alpha. The present study also is in agreement with [12] who found the
Cronbach's alpha to be 0.902 , which indicates a high level of internal consistency for the adapted Arabic HHIE-S.

The psychometric evaluation of the developed HHIE was conducted on a population of 40 individuals. HHIE categorized 28 as having a handicap (mild-tomoderate in nine, and severe in 19). A significant association was demonstrated between the presence or absence of hearing complaints and the HHIE 
Table 5 The demographic data of the participants (40 subjects) in stage 3

\begin{tabular}{|c|c|c|c|c|c|}
\hline \multirow{2}{*}{\multicolumn{2}{|c|}{ No of study subgroups }} & & \multirow{2}{*}{$\frac{\text { Non-comp. }}{20}$} & \multicolumn{2}{|l|}{ Comp. } \\
\hline & & & & 20 & $P$ \\
\hline \multicolumn{3}{|c|}{ Mean of Age } & $64.9 \pm 3.11$ & $64.85 \pm 4.0$ & 0.8 \\
\hline \multirow[t]{6}{*}{ Gender } & Female & Count & 9 & 8 & 17 \\
\hline & & $\%$ & $45.0 \%$ & $40.0 \%$ & $42.5 \%$ \\
\hline & Male & Count & 11 & 12 & 23 \\
\hline & & $\%$ & $55.0 \%$ & $60.0 \%$ & $57.5 \%$ \\
\hline & Total & Count & 20 & 20 & 40 \\
\hline & & $\%$ & $100.0 \%$ & $100.0 \%$ & $100.0 \%$ \\
\hline \multirow{2}{*}{\multicolumn{2}{|c|}{ Pearson chi-square }} & Value & & $p$ & \\
\hline & & .102 & & .749 & \\
\hline
\end{tabular}

categorization (Table 6). A similar pattern of HHIE categorization has been reported previously by [13] among 30 individuals with an HHIE-identified handicap; six had a mild-to-moderate handicap, and 24 had a severe handicap. Also, this result agrees with [12] who found a high statistical significant difference between the group with hearing loss and without hearing loss as regards Arabic (HHIE-S) score $16.60 \pm 10.40$ and $3.50 \pm 2.80$, respectively.

In our study subgroup of 20 individuals with no complaints of hearing impairment, eight were categorized by HHIE as having handicaps. The identified handicaps were mild-to-moderate in seven of these individuals, suggesting that they were still emerging and were at a level enabling them to be ignored or at least not reported. The slow progression of hearing loss can enable affected individuals to make adjustments before a clear awareness of the impairment and its consequences emerge [14]. Notably, in our study subgroup of 20 individuals who all had complaints of hearing impairment, $90 \%$ had severe handicaps according to the HHIE. This corresponded with the fact that they were subjects complaining about hearing impairment.
The specificity of the Arabic version of the HHIE questionnaire was $64 \%$. The efficacy of the questionnaire was $72 \%$. The sensitivity of the questionnaire (HHIE) was $20 \%$ in mild-moderate hearing loss cases but was $80 \%$ for severe hearing loss.

In our study, the overall specificity of the Arabic HHIE for identification of individuals without PTAcategorized hearing loss was $64 \%$, and the sensitivity for identification of those with hearing loss was $75 \%$. In one previous study, for the identification of those with and without severe hearing loss, the specificity of the HHIE was $64 \%$ and its sensitivity was $73 \%$ [15]. In another study, overall HHIE specificity was $67 \%$ and sensitivity was $83 \%$ [16]. We also calculated sensitivities of $24 \%$ for the ability of an HHIE categorization of mild-tomoderate handicap to identify mild-to-moderate hearing loss and $79 \%$ for the ability of an HHIE categorization of severe handicap to identify severe-toprofound hearing loss. In a previous study, sensitivity of the HHIE-S was $15 \%$ for mild hearing loss and $85 \%$ for severe hearing loss [17]. In another study, the HHIE had a sensitivity of $60 \%$ for moderate and severe hearing loss [18]. This may be because patients in this study were mainly retirees in a rural setting; hence, the possibility of limited exposure to noise may have precluded their ability to notice of any hearing problems. Some patients may not report hearing loss in quiet settings but have difficulty understanding speech in social settings where the ambient noise interferes with auditory acuity.

\section{Conclusion}

The developed Arabic version of the HHIE has high reliability, validity, simplicity, and clarity which was found consistent with the original English questionnaire and it performed well in the detection of hearing loss in elderly Egyptians. It can be applied in a large population and for use in surveys.

Table 6 Hearing handicap assessment with the Arabic Hearing Handicap Inventory for the Elderly (HHIE) in two study subgroups

\begin{tabular}{lllll}
\hline HHIE results & & Study subgroup & Hearing complaints \\
\cline { 3 - 5 } & & No hearing complaints & 0 & 12 \\
\hline No handicap & $n$ & 12 & 0 & 30 \\
Mild-to-moderate handicap & $\%$ & 60 & 2 & 9 \\
Severe handicap & $n$ & 75 & 10 & 22.5 \\
& $\%$ & 1 & 90 & 18 \\
Total & $n$ & 5 & 20 & 100 \\
\end{tabular}




\section{Abbreviations}

HHIE: Hearing Handicap Inventory for the Elderly; PTA: Pure-tone audiometry

\section{Acknowledgements}

None.

\section{Authors' contributions}

$\mathrm{NI}$ interpreted the patient data and have approved the submitted version, and AS the acquisition, analysis of patient data, and have approved the submitted version. RB (CA) analyzed and interpreted the patient data, substantively revised it, and was a major contributor in writing the manuscript. HK design of the work and performed examination of the patients, and MA had drafted the work. All authors have read and approved the manuscript and ensured that this is in the case.

\section{Funding}

No funding source.

\section{Availability of data and materials}

The datasets used and/or analyzed during the current study are available from the corresponding author on reasonable request.

\section{Ethics approval and consent to participate}

This study was ethically approved in September 2016 by the ethical committee at the Faculty of Medicine for Girls, Al-Azhar University; the committee reference number is not available. Verbal consent to participate in the study had been obtained from participants before participation in this study and this was approved by the ethical committee.

\section{Consent for publication}

Not applicable.

\section{Competing interests}

The authors declare that they have no competing interests.

\section{Author details}

${ }^{1}$ ENT Department, Faculty of Medicine for Girls, Al-Azhar University, Cairo, Egypt. ${ }^{2}$ Professor of Audio-Vestibular Medicine, ENT Department, Ain-Shams University, Cairo, Egypt. ${ }^{3}$ Master degree of Audio_vestibular Medicine, Cairo, Egypt.

Received: 7 March 2020 Accepted: 26 April 2020

Published online: 04 June 2020

\section{References}

1. Zhang M., Nahla G. and Allan H (2013) Presbycusis. International Journal of Otolaryngology Vol. (2), 111-120.

2. Ventry IM, Weinstein BE (1982) The hearing handicap inventory for the elderly: a new tool. Ear Hear 3(3):128-134

3. Schow R. and Gatehouse S (1990) Fundamental issues in self-assessment of hearing. Ear Hear 11, 6S-16S.

4. Wiley T., Cruickshanks T. and Nondahl D (2000) Self-reported hearing handicap and audiometric measures in older adults. J Am Acad., 43(40): 6-9.

5. ASHA: American Speech-Language-Hearing Association. Report on audiological screening. American Journal of Audiology. (1995) 4, 24-40.

6. ASHA: American Speech-Language-Hearing Association. Guidelines for audiological screening. ASHA Panel on Audiological Assessment 1997.6, 3-4.

7. Guillemin F, Bombardier C, Beaton D (1993) Cross-cultural adaptation of health-related quality of life measures: literature review and proposed guidelines. J Clin Epidemiol 46:1417-1432

8. $\mathrm{WHO}_{\text {, }}$ Report of the Informal Working Group on Prevention of Deafness and Hearing Impairment Programme Planning (1991). Geneva.

9. WHO (2001) International classification of functioning, disability and health World Health Organization, Geneva

10. EUWG: European Work Group on Genetics of Hearing Impairment. Martin A. (ed.), Biomedical and health research programme: hereditary deafness, epidemiology and clinical research (HEAR). Infoletter 2006, 2:19.

11. Crispim M., Ferreira P., Silva L. and Ribeiro E (2013) Analysis of hearing impairment related to general health conditions in elderly people. Gerenc. Polit. Salud Vol.12 no.25.
12. Weinstein B, Rasheedy D, Taha H, Fatouh F (2015) Cross-cultural adaptation of an Arabic version of the 10-item hearing handicap inventory. Int J Audiol 54:341-346

13. Chin and Tong $\mathrm{H}_{\text {., }}$ : Screening for $\mathrm{H}_{\mathrm{I}} \mathrm{l}$ in a cohort elderly. Singapore Med Journal. 2004 Vol. 45(2): 79-84.

14. Arlinger S (2003) Negative consequences of uncorrected hearing loss -a review. Int J Audiol 42:2S17-2S20

15. Wilson PS, Fleming DM, Donaldson I (1993) Prevalence of hearing loss among people aged 65 years and over: screening and hearing aid provision. Br J Gen Pract 43:406-409

16. Abyad A (2004) Screening for hearing loss in the elderly. J Can Geria Soc 20: 20-21

17. Tomioka K, Ikeda H, Hanaiek A (2013) HHIE-S versus a single question: reliability, validity and QOL in elderly community. Qual life Res. 22:11511159

18. Rosdina A, Leelavathi M, Azimah M (2011) Screening for HI among elderly using HHIE-S. New Iraqi J Med. 7(3):68-72

\section{Publisher's Note}

Springer Nature remains neutral with regard to jurisdictional claims in published maps and institutional affiliations.

\section{Submit your manuscript to a SpringerOpen ${ }^{\circ}$ journal and benefit from:}

- Convenient online submission

- Rigorous peer review

- Open access: articles freely available online

- High visibility within the field

- Retaining the copyright to your article

Submit your next manuscript at $\boldsymbol{\nabla}$ springeropen.com 